minds toy with the notion of sterilizing newborn children once a certain quota has been reached ? The signatories of the round robin may think it unfair that such foolish motives should be attributed to them, but a vague call for "appropriate legislation" is likely to provoke precisely such curiosity. Indeed, that is the morbid kind of speculation which exaggerated declarations of crisis is likely to set in train. But few people will, of course, complain at the moderate proposals for an extension of family planning, with contraceptives on the National Health Service, the better conduct of abortions under the NHS and the "reappraisal of the laws and policies which govern the employment of women".

For people who say that the mass media, as they are called, must play an integral role in the whole operation, the doctors have been injudicious. They have addressed themselves to the wrong problem. In the first place, there is no reason to fear that a country such as Britain will find it more difficult in future than it has been in the past four decades to strike a reasonable balance between fecundity and death. By now, the influences which lead to larger families are comparatively well understood. Improved education is a step in the right direction, not merely because it makes people better able to look after their personal affairs but because it provides parents with an incentive to do the best they can for their children, something only easily possible when families are small. Prosperity also helps and, by extension, so does a narrowing of the gap between rich and poor.

But these are goals which many people hold to be desirable in themselves. Might it not have been prudent for the distinguished doctors to have cast their thoughts more widely to encompass these questions? There remains the difficulty of knowing what the population of a country such as Britain should be. In spite of a great deal of academic discussion in the past few years, it is now clear that there are no easy rules of thumb. One thing is however clear. If by some means the number of births each year were to decline more rapidly than it has done in the past few years, some decades hence a smaller working population would have to support a still larger population of unproductive people than at present. To say that is not to imply that a reduction of the number of births each year is out of the question but merely that such a reduction would bring serious but calculated economic penalties.

The same unreflectiveness appears to have marred The Ecologist's "Blueprint for Survival". Those who have compiled it say that "the relevant information available has impressed upon us the extreme gravity of the global situation today". They foresee "the collapse of society" and consider that if present trends persist, "life support systems on this planet" will be irreversibly disrupted if not by the end of the century then "within the lifetime of our children". Governments, they say, are either refusing to face facts or are "briefing their scientists in such a way that their seriousness is played down". So, the argument goes, there must be a redefinition of the philosophy of civilized life and a restructuring of society as a whole.

The errors in this simplistic view of the present stage in the history of the human race are by now familiar. Much turns on the way in which industrialized societies are at present consuming raw materials at a substantial rate, and it is true that it seems increasingly unlikely that petroleum companies will be able indefinitely to discover new reserves at such a pace that future supplies are always ensured. Oil, indeed, may be the most vulnerable of the resources at present used, just as in Europe 2000 years ago native stands of timber proved not to be inexhaustible. But does it follow from this simple-minded calculation that there will come a time when, to everybody's surprise, petroleum deposits are worked out and industry is forced to grind to a halt ? Is it not much more likely, about a century from now, that prices for petroleum will be found to be so high that even the least successful nuclear power companies will find themselves able to sell reactors more easily?

In the same way, is it not likely that the apparently impending scarcity of copper (belied for the time being by the obstinately low price at which the metal is at

\title{
Survival Signatories
}

A statement in The Ecologist says that the undersigned, without endorsing every detail, fully support the basic principles embodied in the Blueprint for Survival both in respect of the analysis of the problems we face today, and the solutions proposed.

Professor Don Arthur (King's College, London); Professor D. Bryce-Smith (University of Reading); Sir Frank Fraser Darling ; Professor G. W. Dimbleby (Institute of Archaeology, London); Professor George Dunnet (University of Aberdeen); Dr P. N. Edmunds (Fife District Laboratory); Professor R. W. Edwards (University of Wales Institute of Science and Technology); Dr S. R. Eyre (University of Leeds); Professor Douglas Falconer (University of Edinburgh); Professor John Friend (University of Hull) ; Professor F. W. Grimes (Institute of Archaeology, University of London); Professor John Hawthorn (University of Strathclyde) ; Professor G. Melvyn Howe (University of Strathclyde) ; Sir Julian Huxley; Dr. David Lack (University of Oxford); Dr J. P. Lester (British Medical Association); Dr John A. Loraine (MRC Clinical Endocrinology Unit,

Edinburgh); Diana G. M. Loraine; Dr Aubrey Manning (University of Edinburgh); Professor Vincent Marks (University of Surrey); Professor Ivor Mills (University of Cambridge) ; Dr E. Mishan (London School of Economics and American University, Washington); Professor P. J. Newbould (The New University of Ulster); Professor Forbes W. Robertson (University of Aberdeen); Professor W. A. Robson (London School of Economics) ; Dr J. Rose (Institute of Environmental Sciences); Sir Edward Salisbury; Dr R. Scorer (Imperial College London); Peter Scott (Wild Fowl Trust); Dr Malcolm Slesser (University of Strathclyde); Professor C. H. Waddington (University of Edinburgh); Dr Watson (University of Strathclyde); Professor V. C. Wynne-Edwards (University of Aberdeen and Natural Environment Research Council). 